\title{
Inhibition of copper pitting corrosion in alkaline sulphate media by benzotriazole at elevated temperatures
}

\author{
E. A. Skrypnikova, ${ }^{1}$ S. A. Kaluzhina ${ }^{2}$ and L. E. Agafonova ${ }^{2}$ \\ ${ }^{1}$ MESC Air Force Military Air Academy named after N. E. Zhukovsky and Yu. A. Gagarin, \\ ul. Staryh bolshevikov 54a, Voronezh, 394000 Russian Federation \\ ${ }^{2}$ Voronezh State University, Universitetskaya pl. 1, Voronezh, 394006 Russian Federation \\ E-mail: kaluzhina@vmail.ru
}

\begin{abstract}
Using complex physical and chemical methods (voltammetry, chronoamperometry, microscopy), the inhibitive action of benzotriazole (BTAH) on copper pitting corrosion (PC) was investigated in alkaline-sulphate solutions in a range of temperatures $\left(20-60^{\circ} \mathrm{C}\right)$. It was found that in the background electrolyte $\left(1 \times 10^{-2} \mathrm{M} \mathrm{NaOH}+1 \times 10^{-2} \mathrm{M} \mathrm{Na}_{2} \mathrm{SO}_{4}\right.$ ( $\mathrm{pH}$ 12)), the intensity of copper PC increases with a temperature growth, whereas addition of an adsorptive inhibitor, namely BTAH, increases the resistance of copper to PC at all the temperatures studied and that the effect is the stronger, the higher the temperature is. Full suppression of PC occurs at $C(\mathrm{BTAH})=8 \times 10^{-4} \mathrm{M}\left(20^{\circ} \mathrm{C}\right)$ and at $C(\mathrm{BTAH})=5 \times 10^{-7} \mathrm{M}$ $\left(60^{\circ} \mathrm{C}\right)$. An explanation of the observed effects was suggested from the viewpoint of modern theories of pitting initiation, adsorption and complex formation phenomena.
\end{abstract}

Key words: copper, pitting corrosion, elevated temperature, benzotriazole.

Received: December 21, 2013.

doi: $\underline{10.17675 / 2305-6894-2014-3-1-059-065}$

\section{Introduction}

Copper and its alloys are widely used in various types of process equipment because of their relatively high corrosion resistance $[1,2]$. However, upon their operation in heat exchange and water supply systems they could undergo various types of local corrosion. Of these, pitting corrosion (PC) is particularly dangerous $[3,4]$. This type of corrosion develops on copper and its alloys in alkaline and soft carbonate waters in the presence of $\mathrm{Cl}^{-}, \mathrm{CNS}^{-}, \mathrm{NO}_{3}^{-}$, and $\mathrm{SO}_{4}^{2-}$ ions [4].

Inorganic and organic inhibitors are widely used for PC suppression in closed cycle systems together with electrochemical methods of protection, but their action mechanisms vary significantly [1]. Among organic copper corrosion inhibitors preference is given to heterocyclic azole compounds because of a number of useful properties (good solubility in water, high thermal stability, ecologic and economic advantages, etc. [5]) that are well studied in practice of protection of copper against general corrosion. At the same time, the issues of their use as copper PC inhibitors are rarely covered in the literature, especially under elevated temperature conditions that occur in heat exchange equipment of water supply systems. 
In view of this, a systematic study of the inhibitive action of one azole representative (benzotriazole, hereinafter referred to as BTAH) on copper PC in alkaline sulphate solutions under elevated temperature conditions has been conducted in the present work.

\section{Experimental}

The experiments were carried out in a glass three electrode electrolytic cell $\left(V=0.250 \mathrm{dm}^{3}\right)$ with non-separated cathode and anode spaces. A copper plate $(\mathrm{M} 1,99.9 \mathrm{wt} \% \mathrm{Cu})$ mounted in epoxy resin and having a working surface of $S=7.85 \times 10^{-5} \mathrm{~m}^{2}$ played the role of the electrode. A silver chloride electrode $(E=0.200 \mathrm{~V}$ (NHE)) was used as the reference electrode, which was connected with the working electrode through a salt bridge filled by a working solution and having a Haber-Luggin capillary at the end. A platinum counter electrode was used.

The background electrolyte had the following composition: $1 \times 10^{-2} \mathrm{M} \mathrm{NaOH}+$ $1 \times 10^{-2} \mathrm{M} \mathrm{Na}_{2} \mathrm{SO}_{4}(\mathrm{pH} 12)$. The concentrations BTAH in the system were varied from $1 \times 10^{-7}$ to $1 \times 10^{-3} \mathrm{M}$. All electrolytes were prepared from analytical grade chemicals using distilled water. The studies were carried out in the temperatures range from 20 to $60^{\circ} \mathrm{C}$. In the experiments at elevated temperatures, the electrolytic cell was placed in an LW-4 water bath (the temperature in the latter was maintained to within $\pm 1^{\circ} \mathrm{C}$ ). The working cell temperature was monitored with a mercury thermometer.

The following physicochemical methods were used to obtain systematic and valid experimental data: inversion voltammetry (IVA), cyclic voltammetry (CVA), chronoamperometry, and microscopy methods. The studies were carried out using a P$5827 \mathrm{M}$ potentiostat and a potential scan rate of $4 \mathrm{mV} / \mathrm{s}$. Monitoring of the copper surface before and after the experiment was performed using a MBS-2 (at a magnification of $\times 7$ ) and a MIM-7 (at a magnification of $\times 500$ ) microscopes.

Prior to each experiment, the surface of the electrode was polished with abrasive papers with gradually decreasing grain size, degreased with alcohol, rinsed with distilled water, and dried with filter paper. After being dipped in the electrolyte, the electrode underwent cathodic pre-polarization $(E=-1.000 \mathrm{~V} ; \tau=10 \mathrm{~min})$, and then the electrode was studied by potentiodynamic method (recording of IVA or CVA curves in the potential range from -1.000 to $+0.800 \mathrm{~V}$ ). The electrode potential was always recalculated versus normal hydrogen electrode (NHE).

The PC potential $\left(E_{\mathrm{PC}}\right)$ and the PC induction period $\left(\tau_{\text {ind }}\right)$ were used as the basic quantitative characteristics of copper PC process [6], assuming that $1 / \tau_{\text {ind }}$ was proportional to the $\mathrm{PC}$ rate.

Thus the efficiency of BTAH as a PC inhibitor [7] was determined as coefficient $Z$, which in the systems of interest was calculated by the following equation:

$$
Z=\frac{\left(1 / \tau_{\text {ind }}\right)_{0}-\left(1 / \tau_{\text {ind }}\right)_{\text {inh }}}{\left(1 / \tau_{\text {ind }}\right)_{0}} \times 100 \%,
$$


where $\left(1 / \tau_{\text {ind }}\right)_{0}$ and $\left(1 / \tau_{\text {ind }}\right)_{\text {inh }}$ are the PC rates in the background electrolyte and in the electrolyte with inhibitor added, respectively.

\section{Results and discussion}

Analysis of the results obtained has shown that in $1 \times 10^{-2} \mathrm{M} \mathrm{NaOH}+1 \times 10^{-2} \mathrm{M} \mathrm{Na}_{2} \mathrm{SO}_{4}$ (background electrolyte) at $20^{\circ} \mathrm{C}$, copper undergoes $\mathrm{PC}$ at $E_{\mathrm{PC}}>E_{i=0}$. This is supported by the following data: 1) an anodic current hysteresis loop in the cyclic voltammograms (CVA) (Fig. 1a); 2) the results of chronoamperometric studies, according to which $E_{\mathrm{PC}}=$ $0.390 \mathrm{~V}$ and $\left(\tau_{\text {ind }}\right)_{0}=60 \mathrm{~s}$ (Fig. $1 b$ ). These electrochemical data are confirmed by the results of microscopic observations, according to which the metal surface after a CVA experiment is covered by numerous small pits (Fig. 1c). It is known [8] $\mathrm{Cu}_{2} \mathrm{O}, \mathrm{CuO}$, and $\mathrm{Cu}(\mathrm{OH})_{2}$ are responsible for the complex shape of the anodic polarization curve on copper in an alkaline sulphate background solution at $20^{\circ} \mathrm{C}$.

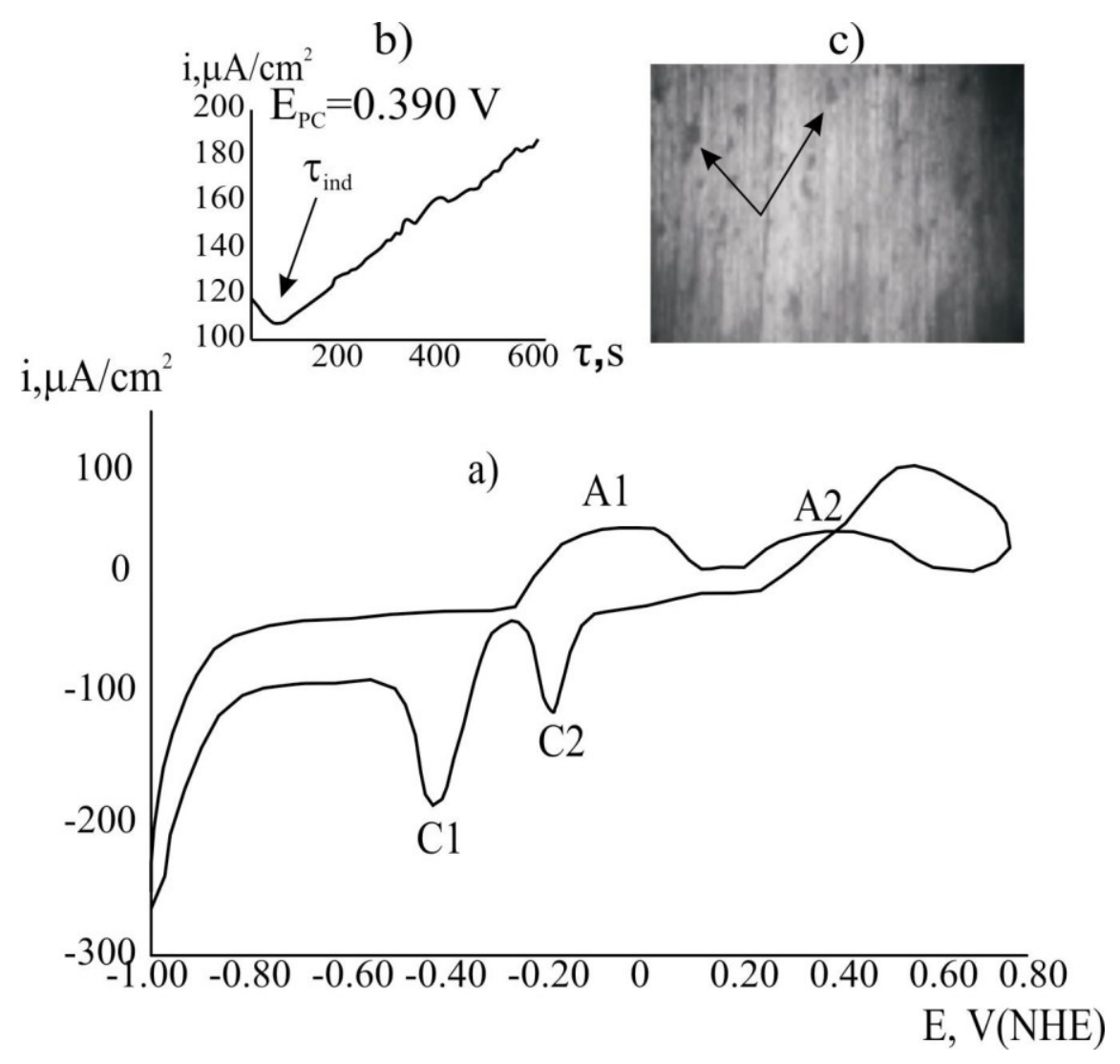

Figure 1. (a) A CVA of copper in $1 \times 10^{-2} \mathrm{M} \mathrm{NaOH}+1 \times 10^{-2} \mathrm{M} \mathrm{Na}_{2} \mathrm{SO}_{4}$ solution at $20^{\circ} \mathrm{C}$, where $\mathrm{A} 1 / \mathrm{C} 1-\mathrm{Cu} / \mathrm{Cu}_{2} \mathrm{O}, \mathrm{A} 2 / \mathrm{C} 2-\mathrm{Cu}_{2} \mathrm{O} / \mathrm{CuO}, \mathrm{Cu}(\mathrm{OH})_{2} ;(b)$ a chronoamperogram at $E_{\mathrm{PC}}=$ $0.390 \mathrm{~V} ;(c)$ a micrograph of the local damage on the copper surface $((\times 500)$ MIM-7).

Addition of BTAH to the background electrolyte in the concentration range of $1 \times 10^{-6}$ to $5 \times 10^{-4} \mathrm{M}$ causes an insignificant decrease in the height of the anodic peaks (Fig. 2). Addition of the inhibitor stabilizes the system: $E_{\mathrm{PC}}$ shifts to more positive values and the 
number of pits decreases, but their depth remains constant and loose transparent blue layers appear on the copper surface. The latter, according to [9], is due to the formation of a copper-benzotriazolate hydrate complex. At the same time, the BTAH efficiency as a PC inhibitor, $Z$, increases from $25 \%$ to $70 \%$ with an increase in concentration (Table 1).

b)

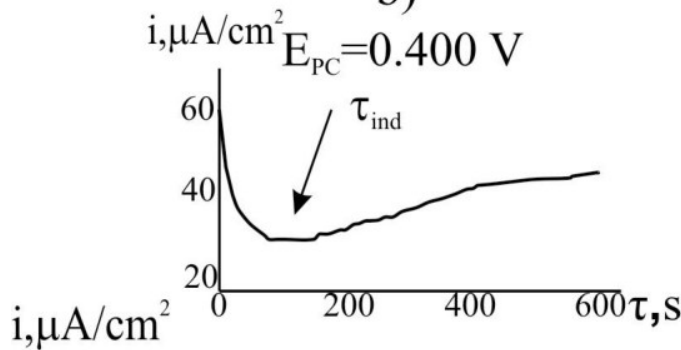

c)
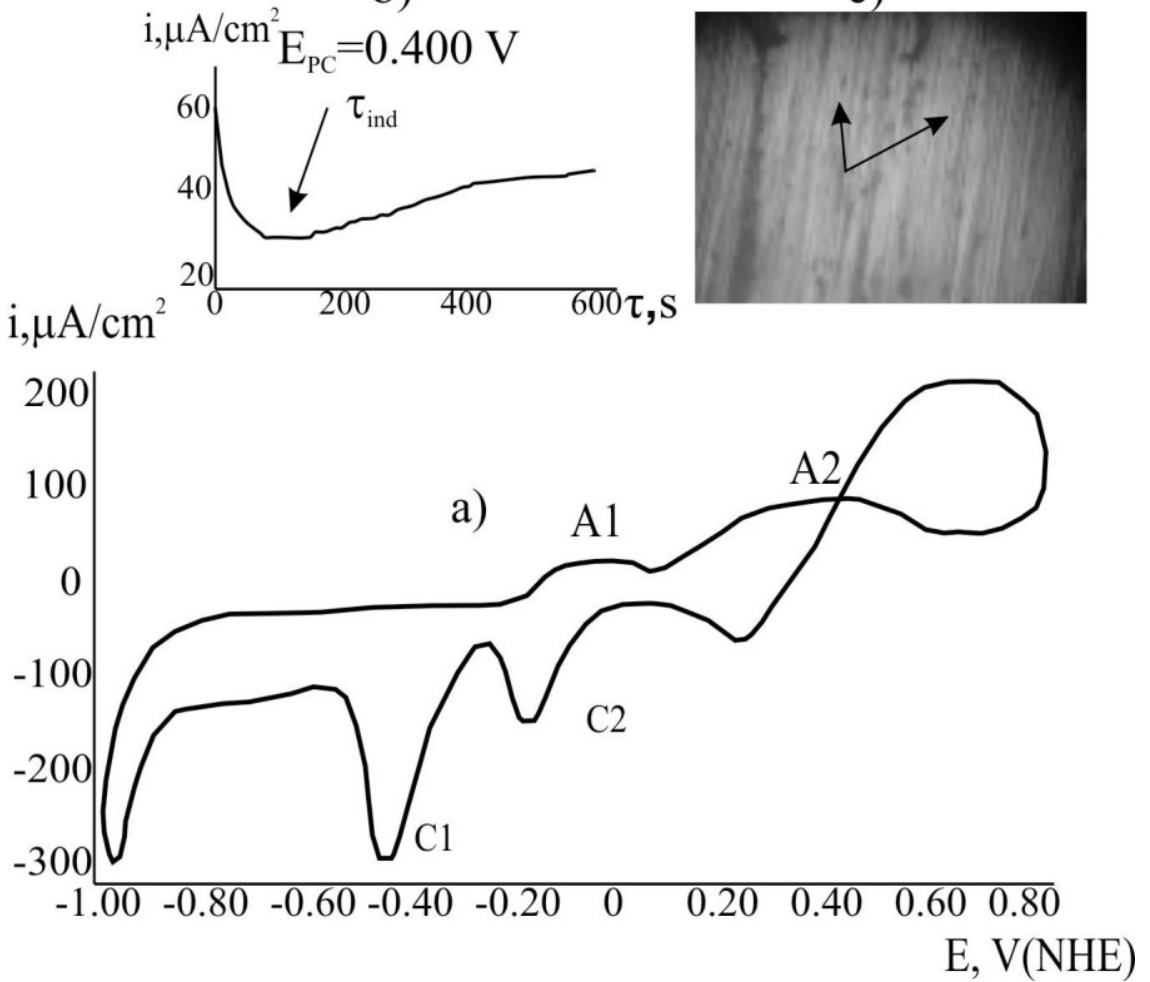

Figure 2. (a) A CVA of copper in $1 \times 10^{-2} \mathrm{M} \mathrm{NaOH}+1 \times 10^{-2} \mathrm{M} \mathrm{Na}_{2} \mathrm{SO}_{4}+1 \times 10^{-6} \mathrm{M} \mathrm{BTAH}$ solution at $20^{\circ} \mathrm{C}$, where $\mathrm{A} 1 / \mathrm{C} 1-\mathrm{Cu} / \mathrm{Cu}_{2} \mathrm{O}, \mathrm{A} 2 / \mathrm{C} 2-\mathrm{Cu}_{2} \mathrm{O} / \mathrm{CuO}, \mathrm{Cu}(\mathrm{OH})_{2} ;(b)$ a chronoamperogram at $E_{\mathrm{PC}}=0.400 \mathrm{~V} ;(c)$ a micrograph of local damage on the copper surface $((\times 500)$ MIM-7).

Upon increasing the BTAH concentration to $C \geq 8 \times 10^{-4} \mathrm{M}$, full protection of copper against local destructions was observed (Table 1). It was confirmed by the absence of pits on the electrode surface after the experiment and transition of the system to a stable passive state.

In order to estimate the effect of BTAH on copper PC in alkaline sulphate media at elevated temperatures, a preliminary study of the metal electrochemical behavior in background electrolytes in the temperatures range of $20-60^{\circ} \mathrm{C}$ in the absence of the inhibitor was carried out. The results have shown that an increase in the background electrolyte temperature from 20 to $60^{\circ} \mathrm{C}$ caused an amplification of copper PC. This effect was confirmed by an increase in the PC rate $\left(1 / \tau_{\text {ind }}\right)_{0}$ (according to the Arrhenius dependence) correlated with the increase in the average pit depth (Table 2) at constant $E_{\mathrm{PC}}$. 
Table 1. Effect of BTAH concentration on copper PC process in $1 \times 10^{-2} \mathrm{M} \mathrm{NaOH}+1 \times 10^{-2} \mathrm{M} \mathrm{Na}_{2} \mathrm{SO}_{4}+$ $\mathrm{X} \mathrm{M}$ BTAH solution at $20^{\circ} \mathrm{C}$.

\begin{tabular}{|c|c|c|c|c|c|}
\hline Electrolyte & $\tau_{\text {ind }}, \mathbf{s}$ & Pit depth, $\mu \mathrm{m}$ & Surface & $E_{\mathrm{PC}}, \mathbf{V}$ & $Z, \%$ \\
\hline Background & 60 & 3 & & 0.390 & - \\
\hline $\begin{array}{c}\text { Background }+ \\
1 \times 10^{-6} \mathrm{M} \mathrm{BTAH}\end{array}$ & 80 & $<3$ & & 0.400 & 25 \\
\hline $\begin{array}{c}\text { Background }+ \\
1 \times 10^{-5} \mathrm{M} \mathrm{BTAH}\end{array}$ & 95 & $<3$ & & 0.430 & 37 \\
\hline $\begin{array}{c}\text { Background }+ \\
1 \times 10^{-4} \mathrm{M} \mathrm{BTAH}\end{array}$ & 100 & $<3$ & & 0.440 & 40 \\
\hline $\begin{array}{c}\text { Background }+ \\
5 \times 10^{-4} \mathrm{M} \mathrm{BTAH}\end{array}$ & 200 & $<3$ & & 0.440 & 70 \\
\hline $\begin{array}{c}\text { Background }+ \\
8 \times 10^{-4} \mathrm{M} \mathrm{BTAH}\end{array}$ & - & - & & - & 100 \\
\hline
\end{tabular}

Table 2. Effect of temperature on copper $\mathrm{PC}$ in $1 \times 10^{-2} \mathrm{M} \mathrm{NaOH}+1 \times 10^{-2} \mathrm{M} \mathrm{Na}_{2} \mathrm{SO}_{4}$ solution.

\begin{tabular}{ccccc}
\hline Solution & $\boldsymbol{t},{ }^{\circ} \mathbf{C}$ & Pit depth, $\boldsymbol{\mu m}$ & $\left(\boldsymbol{\tau}_{\text {ind }}\right)_{\mathbf{0}}, \mathbf{s}$ & $\boldsymbol{E}_{\mathbf{P C}}, \mathbf{V}$ \\
\hline Background & 20 & 3 & 60 & 0.390 \\
Background & 40 & 9 & 50 & 0.390 \\
Background & 50 & 15 & 30 & 0.390 \\
Background & 60 & 21 & 20 & 0.390 \\
\hline
\end{tabular}

Additional studies have shown that an increase in temperature increases the BTAH inhibitive efficiency (Table 3).

Table 3. Effect of temperature on $Z$ of BTAH in $1 \times 10^{-2} \mathrm{M} \mathrm{NaOH}+1 \times 10^{-2} \mathrm{M} \mathrm{Na}_{2} \mathrm{SO}_{4}+1 \times 10^{-6} \mathrm{M}$ BTAH.

\begin{tabular}{ccccc}
\hline $\boldsymbol{t},{ }^{\circ} \mathbf{C}$ & $\mathbf{2 0}$ & $\mathbf{4 0}$ & $\mathbf{5 0}$ & $\mathbf{6 0}$ \\
\hline$Z, \%$ & 25 & 31 & 43 & 100 \\
\hline
\end{tabular}


The observed effects can be interpreted based on detailed consideration of the mechanisms of the processes studied. Earlier [10] it was found that in the background electrolyte $\left(1 \times 10^{-2} \mathrm{M} \mathrm{NaOH}+1 \times 10^{-2} \mathrm{M} \mathrm{Na}_{2} \mathrm{SO}_{4}\right)$, the $\mathrm{PC}$ process occurs by the adsorption-penetration mechanism. In view of this, the PC process can be presented as substitution of oxygen-containing passivating particles by corrosive anions in the surface complex (reaction A) followed by generation of a cation vacancy-anion vacancy pair via a Schottky type reaction and migration of the cation vacancies from the film/electrolyte interface to the metal/film interface. The cation vacancies are accumulated near the latter interface with formation of voids resulting in breakdown of the passive film and local damage $[11,12]$.

$$
\left[\mathrm{Me}(\mathrm{OH})_{m}\right]^{z_{1}-m}+L \mathrm{An}^{-} \rightarrow\left[\mathrm{Me}(\mathrm{OH})_{m-L} \mathrm{An}_{L}\right]^{z_{2}-m}+L\left(\mathrm{OH}^{-}\right)+\left(z_{1}-z_{2}\right) \overline{\mathrm{e}}
$$

But under simultaneous presence in electrolyte aggressive $\left(\mathrm{SO}_{4}{ }^{2-}\right)$ and inhibitor ions $\left(\mathrm{BTA}^{-}\right.$), the last (as more powerful nucleophile ) predominantly adsorbs at the most electrophile or the most dangerous for PC sites of passive film and block them:

$$
\left[\mathrm{Me}(\mathrm{OH})_{m}\right]^{z_{1}-m}+L \mathrm{Inh} \rightarrow\left[\mathrm{Me}(\mathrm{OH})_{m-L} \mathrm{Inh}\right]^{z_{4}-m}+L\left(\mathrm{OH}^{-}\right)+\left(z_{1}-z_{4}\right) \overline{\mathrm{e}}
$$

The protective action of BTAH is due to its high adsorption ability and formation of a dense insoluble copper benzotriazolate film on the metal surface [13]. On the one hand, this film $[\mathrm{Cu}(\mathrm{I})-\mathrm{BTA}]$ is a physical barrier to corrosive ions, and on the other hand, it inhibits copper anodic dissolution sites. It is known that at $\mathrm{pH}>9$, BTAH is predominantly in the anionic form and can exist as mono- and poly-adsorption $(\mathrm{Cu}-\mathrm{BTA})_{\text {ads }}$ layers on copper surface at the free corrosion potential [14].

$$
\begin{gathered}
\mathrm{Cu}+\mathrm{BTA}^{-} \rightarrow(\mathrm{Cu}-\mathrm{BTA})_{\mathrm{ads}} \\
n \mathrm{Cu}++n \mathrm{BTA}^{-} \rightarrow(\mathrm{CuBTA})_{n} \\
(\mathrm{Cu}-\mathrm{BTA})_{\mathrm{ads}}+(\mathrm{CuBTA})_{n} \rightarrow\left[(\mathrm{Cu}-\mathrm{BTA})-(\mathrm{CuBTA})_{n}\right]
\end{gathered}
$$

In alkaline media, the copper surface contains oxide-hydroxide compounds (the fraction of which increases with temperature rise) and $\mathrm{BTA}^{-}$adsorption on oxide-coated metal sites is preferred and occurs sufficiently fast [15], probably due to the ability of oxygen atoms in the oxide $(\mathrm{Cu}-\mathrm{O}-\mathrm{Cu})$ to form hydrogen bonds with hydrogen atoms of the benzotriazole anion $(\mathrm{C}-\mathrm{H})$. The increase in inhibitor efficiency with temperature raise is probably due to an increase in the fraction of oxygen compounds on the metal surface and an increase in the polymerization degree of the protective film [16], indicating the increase in the protective complex stability.

Thus, experiments demonstrate that in alkaline sulphate electrolytes BTAH forms surface copper complexes [(Cu-BTA $\left.)-(\mathrm{CuBTA})_{\mathrm{n}}\right]$, decreasing its susceptibility to nucleophile attack from $\mathrm{SO}_{4}^{2-}$ ions and making it possible to screen the metal surface. This may be due to low solubility and high stability of the complex. The BTAH efficiency increases with electrolyte temperature due to an increase in the degree of polymerization of the protective film. 


\section{Conclusion}

Analysis of the results obtained allows us to conclude that BTAH can be used as an efficient copper PC inhibitor in heat exchange equipment and water supply systems. It has been found that its efficiency grows with increase in temperature and full metal protection against pitting corrosion occurs at the following BTAH concentrations: $8 \times 10^{-4} \mathrm{M}$ $\left(40^{\circ} \mathrm{C}\right) \rightarrow 2 \times 10^{-6} \mathrm{M}\left(50^{\circ} \mathrm{C}\right) \rightarrow 5 \times 10^{-7} \mathrm{M}\left(60^{\circ} \mathrm{C}\right)$.

This study was supported by the Ministry of Education and Science of RF (Project RNP 08-03-00194).

\section{References}

1. F. Todt, Korroziya i zashchita ot korrozii (Corrosion and Corrosion Protection), Moscow, Khimiya, 1966 (in Russian).

2. N. D. Tomashov and G. P. Chernova, Passivnost' $i$ zashchita metallov ot korrozii (Passivity and Corrosion Protection of Metals), Moscow, Nauka, 1965 (in Russian).

3. G. G. Uhlig, Korroziya i bor'ba s nei. Vvedenie v korrozionnuyu nauku i tehniku (Corrosion and Corrosion Prevention. Introduction to Corrosion Science and Technology), Leningrad, Khimiya, 1989 (in Russian).

4. V. F. Zycey, Br. Corros. J., 1967, 2, 175.

5. A. I. Altsybeeva and S.Z. Levin, Ingibitory korrozii metallov (Metal Corrosion Inhibitors), Moscow, Khimiya, 1968 (in Russian).

6. L. I. Freiman, Itogi nauki $i$ tehniki: Korroziya $i$ zashchita ot korrozii (Advances in Science and Technology: Corrosion and Corrosion Protection), 1985, 4, 3 (in Russian).

7. I. L. Rozenfel'd, Ingibitory korrozii (Corrosion Inhibitors), Moscow, Khimiya, 1982 (in Russian).

8. M. Pourbax, J. Electrochem. Soc. Reviews and News, 1976, 123, 25.

9. M. Hursthouse, R. Short and S. Robinson, Polyhedron, 1986, 5, 1573.

10. S. A. Kaluzhina and I. V. Kobanenko, Zashch. Met., 2001, 37, 266 (in Russian).

11. Yu. I. Kuznetsov, Sbornik dokladov NIFHI im. Karpova L. Ya., 2000, 1, 161 (in Russian).

12. M. Urquidi-Macdonald and D. Macdonald, J. Electrochem. Soc., 1987, 134, 41.

13. D. Tromans and Ru-hong Sun, J. Electrochem. Soc., 1991, 138, 3235.

14. Y. Hong, V. Devarapalli, D. Roy and S. Babu, J. Electrochem. Soc., 2007, 154, H444.

15. L. Tommesani, G. Brunoro, A. Frignani, C. Monticelli and M. Dal Colle, Corros. Sci., 1997, 39, 1221.

16. D. Tromans, J. Electrochem. Soc., 1998, 145, L42. 